\title{
GREEN TOURISM DEVELOPMENT IN SMART COMMUNITIES
}

\author{
Maria Plotnikova ${ }^{1}$ \\ Zhytomyr National Agroecological University, Ukraine
}

\begin{abstract}
The purpose of the study is to substantiate factors and mechanisms of development of green tourism and its consequences. Methodology. The methodological basis of the study is the systematic synergistic approach to the study of socio-economic phenomena in rural areas under the influence of macroeconomic factors and local initiatives to increase their socio-economic potential through the practice of green tourism. The research used such methods as analysis and synthesis, comparison, and generalization. Historical and logical methods of scientific knowledge, expert evaluations, graphic, and averages are used. The abstract-logical method of research allowed, through theoretical generalizations, to determine the research tasks, to formulate the working hypothesis and conclusions. A survey was conducted on 800 rural residents aged 18-72, of which $56 \%$ were women and $44 \%$ were men from 6 regions of Ukraine, among which $20 \%$ were inhabitants of ecological and tribal settlements. The participants in the survey were persons under 35 years of age (26\% of their total number), persons 35 to 55 years old (accounted for $47 \%$ ), and 55 years and older (27\%). Respondents having higher education were $28 \%$, incomplete higher $-6 \%$, secondary special $-30 \%$, secondary $-33 \%$, others $-3 \%$. Respondents in the social sphere accounted for $30 \%$, agriculture $-26 \%$, pensioners $-23 \%$, forestry $-3 \%$, unemployed persons $-18 \%$, which ensured the representativeness of the sample. The study period covered the years of 2013-2017. Results. As a result of the study, it was established that the development of green tourism is the basis of rational nature management and increasing the competitiveness of the regions through the formation of their investment and socio-environmental attractiveness. The subject of the study is a set of institutional, theoretical-methodological, methodological, and applied problems of the development of green tourism. The conditions and retrospective of tourism development are outlined, among which the priority is to increase the socio-economic activity of the territories with minimal investments of budgets of all levels and a high level of return on investments. The basic problems of the establishment of green (ecological tourism) are identified. The basic ones are the inadequacy of the quality and range of services provided at their prices, as well as the low level of professionalism of the persons providing tourist services. The factors that determine the activation of green tourism in Ukraine are determined. Of these, the development of generic settlements as catalysts of social change in the territory is decisive. Public organizations as institutions of social importance are the triggers of the activity. Practical implications. The practical significance of the research is to deliver a strategy for the development of green tourism in the united territorial communities. They will be able to make proposals for the legislative regulation of the of urban youth transfer to rural areas. Youth that will invest in rural areas and is ready to start their business. Value/originality. The uniqueness of the study is to present the experience of rural areas through the mechanism of Family Homestead, which provides for the provision of legislative rights to every citizen of Ukraine, if they wish to receive 1 hectare of land for the construction of a Family Homestead for lifetime use, free of charge, without the right to sell, with the right to transfer only by inheritance.
\end{abstract}

Key words: green tourism, Family Homestead, rural development, smart-community, united territorial communities.

JEL Classification: D83, O10, R28, Q01, Q18

\section{Introduction}

The dynamic nature of the global socio-economic system, the globalization of phenomena and processes of the world community, and the decentralization of power in Ukraine dictate fundamentally new qualitative requirements for the development of territorial communities, in particular, in rural areas. Tourist activity is an area that reveals significant opportunities for taking into account the unique characteristics of the territory with minimal budget financing compared to other sectors of the economy.

The purpose of the study is to substantiate the factors, mechanisms of development of green tourism, and

Corresponding author:

${ }^{1}$ Department of Innovative Entrepreneurship and Investment Activity, Zhytomyr National Agroecological University.

E-mail:mfplotnikova@gmail.com 
its consequences for the development of rural areas. In connection with the chosen purpose, the following tasks are defined:

1) to study the historical and cultural background of the development of green tourism;

2) to substantiate the principles of management of green tourism in the conditions of the united territorial communities;

3) simulate the prospects for the development of green tourism in rural areas.

The lobbying of own interests from the side of big business, including in the tourism sector at the legislative level, from the point of view of organizing and stimulating activities, etc., reduces the possibilities of meeting the needs of the inhabitants of the territorial communities, increases asymmetries and disproportions to the development of society, is one of the reasons for the migration from rural areas of Ukraine. "Establishment" of a person in the territory in the case with housing, employment (self-employment), cultural and spiritual development, access to natural resources in the unlimited long-term perspective at places of residence is the basis of society's development. Creative approaches allow developing the local economy, taking into account the unique resources of each territory. An important role, in this case, belongs to green tourism, which combines the practice of children's, family, cultural-cognitive, health-improving, sport, rural, adventure, amateur, volunteer tourism.

The authors consider green tourism and its organization as a mechanism for rational use of ecosystems and increase the competitiveness of regions by ensuring their attractiveness, providing recreational, recreational and tourist services (Zinchenko, 2016). A similar position is observed by M. Benner (Benner, 2017), Ch. Machado, L. Esther (Machado, 2017). Researchers focus their attention on hierarchy, selfdevelopment of social, the causes of their emergence and management (Beck, 1995; Lalu, 2016). Ethnic, national, regional features of tourism and sustainable development are an active subject of research (Nizic,
2017; Lupu, 2016). A special place is occupied by resource-saving technologies, waste-free livelihoods as the basis for well-being both locally and nationally (Jaszczak, 2017).

Tourism as an industry determines not only the economic component but also the socio-cultural, educational, and ideological components of development, and implements the multiplier effect in related industries (Dafuleya, 2017; Reyes, 2017) has a great potential in the domestic market of Ukraine. Inconsistency in prices, infrastructure development, low quality and a small range of tourist services, insufficient level of staff, excessive man-made load, insufficient level of culture of visitors to tourist facilities (Bednarska, 2017; Leonidova, 2017) limits the ability to ensure the efficient development of the industry.

The results of the research are used in the educational process of the Zhytomyr National Agroecological University and in the practice of management of territorial communities.

\section{The theoretical basis of green tourism}

The need to intensify domestic tourism through the formation of demand for hotel and restaurant services, taking into account local specifics and the development of family business, is the basis of the local economy, which contributes to the restoration of infrastructure, is wide in price range (from low-budget to elite class), diverse in its specialization and business direction, inclusive in its essence, is a mechanism for popularizing the country on the world stage. The ability to combine social entrepreneurship with volunteering, recreation, education, health improvement, and other activities expands the potential range of services. This is most fully expressed in the practice of green rural tourism (Table 1).

According to the World Tourism Organization, green tourism accounts for $7-20 \%$ of the total tourist services. The largest are revenues from the tourism industry of the United States, France, Spain, the United Kingdom,

Table 1

The spectrum of related activities and alternative services in green tourism

\begin{tabular}{|c|c|}
\hline $\begin{array}{c}\text { Scope } \\
\text { of action }\end{array}$ & Activity \\
\hline 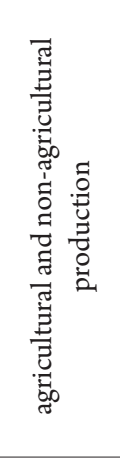 & $\begin{array}{l}\text { 1) production of agricultural products as a final product and raw materials for other types of production - growing } \\
\text { vegetables, fruits, berries, herbs, spices, nuts, mushrooms, medicinal and tea plants, sugar substitutes, cereals, ornamental } \\
\text { plants, seeds and seedlings, including rare plant species; greenhouse economy, including for year-round growing of } \\
\text { vegetables, greens, flowers; production of biohumus, worms, biocompost, soil mixtures, peat and other elements for the } \\
\text { rebirth and growth of soil fertility; cultivation of microalgae (spirulina, chlorella); growing and keeping domestic and } \\
\text { wildlife, including for the purpose of obtaining food (milk, eggs, wool, honey and other bee products), for the purpose of } \\
\text { pollination as a means of transport, the protection of areas, the control of pests and diseases of plants, animals, humans, } \\
\text { as decorative, recreational and health (apitherapy, hippotherapy, etc.) appointment, extension cooperation with reserves, } \\
\text { preserves, zoos, including fish farming, breeding of crayfish, beekeeping, breeding of osmium, bumblebee (pollination of } \\
\text { plants in greenhouses); 2) harvesting wild cherries, including medicinal plants, mushrooms, berries, nuts, moss, maple and } \\
\text { birch sap, etc.; 3) the collection of valuable minerals, healing clays, mud, sapropel; 4) breeding elite breeds of horses, dogs, } \\
\text { cats and other animals, growing hedgehogs, bats; 5) growing and harvesting of forests. }\end{array}$ \\
\hline
\end{tabular}




\section{End of Table 1}

1) sphere of services (gardening and gardening, educational and consulting activities in this area, trade); 2) production from natural raw materials (development of folk crafts and crafts, including courses, master classes, outdoors lessons from warping, carving on wood, bones, pottery art, tailoring, costumes, art painting, joinery and carpentry, blacksmithing , chasing, casting, stone processing, weaving, publishing books, magazines, newspapers); 3) the production of flour, oils, the sale of environmental products and rare products; 4) prophylactic and regenerative medicine, naturopathy, including the departure to health centres, practice of teaching (phytotherapy, bioenergetics, yogic practices, self-improvement practices, naturopathy, valeology, recreational rest, therapeutic exercises, usually healing baths, mud, water, clay, quenching, sweating, massages, psychotherapy, restoration of vision, restoration of health in general, elimination of dependencies, fears, treatment of insects - bees, etc.); 5) organization of sports activities, competitions, sports tourism (sports sections, schools, swimming pools, courts, sports grounds, equestrian sport, cycling, climbing, kayaking and canoeing, skiing grounds, skating rink, martial arts club, including the Savior and Battle hawk, hiking, flight clubs, fitness centres, sports bars, children's camps).

Primary: 1) production of food from agricultural raw materials of vegetable origin (processing, preservation, drying, freezing and preserving of food products, making juices or compotes or fruit drinks, kvass and other non-alcoholic and low alcohol drinks, baking of other products, in particular, cookies, making of natural sweets, macaroni products, production of various types of cold-pressed oil, essential oils of nuts and seeds, natural flavours, perfumes, flavours, production of dried fruits, making of dry breakfasts, walnut mixes, mussels, snacks and semi-finished products, in particular, soup mixes, dumplings, etc., tea production, medical fees, production of products based on sprouted seeds, etc.); 2) growing plants and making them of threads and tissues (nettles, flax, cotton); 3 ) production of food from agricultural raw materials of animal origin (production of milk and lactic acid products, including hard and soft cheeses, sour cream, whey, vitamin mixtures, medicinal preparations, bee products); 4) manufacturing of products from raw material of animal origin (wool collection and manufacture of knitted and woven products); 5) manufacture of cosmetic and medicinal preparations from valuable minerals, medical clay, mud, sapropel; 6) harvesting of clean water, air from natural sources.

Secondary: 1) activities in the field of green tourism, hotel and restaurant industry, catering (dining, dining, food, mill, tea, etc.), medicine (in particular, activities in the field of recovery, prevention and health care); 2) the production of agricultural equipment and repairs, including horns Varra and logs, household items and interior (utensils, furniture, linen, clothes, decoration items); 3 ) activities in the field of information technology (programmers, system administrators, the creation of games, educational programs video clips, films and cartoons, musical works, translation of technical texts, books in foreign languages, the creation of electronic versions of libraries, poetry and art collections, freelance - remote work on the Internet, development and promotion of sites, 3D-modelling, video graphics, photo-video processing, management of inter-shop); 4) activities in the field of creative technologies (designers, PR-technologies, art and design works, including architectural, design furniture, houses, cars, etc.); creation of training courses; 5) installation of alternative energy sources, in particular, solar power plants; 6) creative and intellectual activity (creative activity of artists, musicians, poets, artists, writers, philosophers, organization of outdoor concerts, corporate events, holidays, organization of creative workshops, studios, festivals, theatres).

Social entrepreneurship includes the organization of small industries (in particular, the manufacture of building materials, woodworking, including the manufacture of joiner's products, furniture, etc., the manufacture of solar, wind turbine bioreactors and other power plants, their installation, adjustment and on-site launch, the production of tools and products of restored land use, production of soap, detergents, toothpaste, cosmetics on the basis of natural ingredients, microorganisms, manufacture of boats, natural fabrics, garment production, knitting tapestries, carpets, blankets, electronic products manufacturing, automatics for ecological houses, greenhouses, cellars, warehouses, development and maintenance of environmentally friendly modes of transport, collection of bicycles, electric cars, trailers, environmental auto washing, ceramic production, small flour production, cereals, oils, semi-finished products, bakery, processing of agricultural products, manufacturing of environmental packaging, 3D-Internet production, collection of light aircraft, manufacturing of sport inventory, environmental paints, protective coatings from wax, resins, natural minerals, biocomponents, production of medical products - resinous oils, oils, herbs, bee products, needles, fuel briquettes, pellets, peat, straw and other products from organic, glass blowing, glass production, production of utensils, ceramic goods from clay, stone, production of natural wallpaper, parquet, boards, furniture, mattresses, pillows of vegetable and animal raw materials, sewing of the author $\mathrm{g}$ clothes made of natural fabrics, manufacturing of sports and tourist equipment, goods for recreation and rest, manufacturing of doors, windows, greenhouses, masonry stoves, fireplaces, assembly of electrical products, production of building materials, blocks, mixes, roofing materials, decorative stone, tiles, waste processing).

The most common works and services are: 1) education and upbringing, including foster children (Shchetinin schools, elite schools, family schools, noosphere schools, schools of creativity, technical education colleges, universities of distant higher education, small private universities); 2) scientific activities, including scientific research in the field of agriculture, nature, ecology, in the field of biotechnology development, environmentally friendly technologies, development of alternative energy sources, dissemination of special knowledge, consultations, lectures; 3 ) the organization and training of construction, as well as the type of green tourism (development and erection of houses, facilities and infrastructure, including wells, wells, ponds, fences, communications, lounges, arbors, etc.); 4) organization of tourism activities (green tourism, health tourism, organization of recreation, festivals, take-offs, sports tourism - horseback riding, kayaking, bicycles, scuba diving, hang gliding, gliding, parachute jumping, kiteging, snowboarding, skiing, etc.); 5) transportation (transportation of residents and guests of ecological settlements both in the middle and outside of the settlement, cargo transportation, special transport services for land, construction works, clearing of roads from snow, courier services, etc.); 6) consumer co-operation (joint purchases of products, materials, goods, services from producers or wholesalers). 
and China. Ukraine occupies 69th in this ranking (at the moment, the potential of Ukraine is 150 thousand participants, although cultural figures have been used since ancient times) (Bukowska, 2017). Rural tourism in Europe began to develop from the middle of the nineteenth century and, according to the estimates of the European Federation of Farmer and Rural Tourism (Euro Gites), there are currently 2 million beds. The French government was the first in the EU to initiate the development of green tourism in the early 1950s as a mechanism for alternative employment for farmers traveling to the cities. At present, the industry brings 1 billion USD to the country's budget and 3 billion USD to the budgets of the regions. The activities of public organizations registered in the territory can become a catalyst for change and an activation component that involves external investment, which, unlike grant assistance, does not terminate its activities upon completion of funding.

The priority character of the development of the services sector due to their high level of profitability and a quick payback level allows confirming the need for their activation in rural areas. The low level of budget expenditures, the organizational and legal format for providing activities, the possibility of introducing innovative and creative technologies in life and management, and a variety of conditions within the regions create a prospective basis for the spread of practice in all the communities of the country. Green ecological tourism as a mechanism of socio-economic activation of rural development is approved on the part of governmental structures, public organizations and the world community, while the population of rural areas of Ukraine mainly treats it with disbelief due to unresolved issues on the side of the current legislation and the absence of an appropriate culture on the part of the territorial community as socio-economic unit that accepts tourists as a hub.

Taking into account the experience of the USA (in 1982, the law on development of agrarian, farmer and ecological tourism was adopted), the EU (multifaceted nature of rural tourism and the principles of developing tourist clusters as a set of micro-businesses), the Republic of Belarus (since 2006, the Presidential Decree "On Measures on the Development of Agroecotourism in the Republic of Belarus" and state development programs of agroholding), it is advisable for Ukraine to form a favourable legal field for tourism through the definition of its nature, types, range of services, their status, and professional training.

In Ukraine, rural tourism as a form of recreation in rural areas is regulated by the Laws of Ukraine "On Tourism" (On Tourism, 1995), "On Personal Peasant Economy" (On Personal, 2003). Amendments to the last, adopted in May 2017, green tourism is understood as recreation in the area that is attractive for its integrity, and for the provision of services, registration of a business entity is not required for the provision of services to no more than 10 persons who were not provided with special services (Article 1 of the Law of Ukraine "On Personal Peasant Economy"). As rural tourism, we have in mind paid or free services for accommodation (accommodation), food and leisure, and activities related to the use of property, familiarity with local customs and traditions, hospitality. Farm tourism, in this case, includes the obligatory hiring of housing and monitoring of the work of farms for the production of plant growing and livestock for possible participation in these processes, which provides an active form of rest.

Energy-information exchange of the territory with the guests allows preserving the existing historical and cultural heritage and multiplying the potential of the territory through various forms of communication. The attractiveness of the natural environment, the ability to interact with it is particularly popular among the inhabitants of the metropolis. This format of leisure time is favoured by $35 \%$ of EU residents, of which $20 \%$ combine it with traveling (Bukowska, 2017). From the position of management of such activities within the administrative-territorial formation are as follows (Figure 1). The development of rural areas in the world for a long time is focused on the production of agricultural products, intensive use of land. The most common approaches to the interpretation of the concept of "rural development" are reflected in the table. Their domination became the basis of agrarian policy. The search for mechanisms for the revival of rural areas on the basis of harmonious sustainable development, selfsufficiency of socio-economic and ecological activities is currently relevant within the global system of human development (Nitsenko, 2017).

At present, Family Homesteads as a local format of green tourism development were visited by tourists from the USA, Canada, Poland, Lithuania, Estonia, the Czech Republic, the Netherlands, Sweden, Turkey, Georgia, Belarus, and all parts of Ukraine (Table 2).

Table 2

The dynamics of income from Family Homesteads as a result of the practice of green tourism and investment activities in the territories

\begin{tabular}{|l|c|c|c|}
\hline \multicolumn{1}{|c|}{ Indicators } & 2015 & 2016 & 2017 \\
\hline Number of foreign investors, persons & 1 & 3 & 14 \\
\hline $\begin{array}{l}\text { Amount of revenues from tourism } \\
\text { activity and investments, thousand USD }\end{array}$ & 6 & 20,2 & 90,5 \\
\hline
\end{tabular}

Family Homesteads are a place of residence of the family, the main component of society. Such a site implies the presence of a lovingly built house, planted Gentwood, forest, garden city, a hedge of forest crops, arranged pond. The small homeland, the eternal roots that bind the Earth, helps to feel connected with everything in the universe: with God, nature, planets and stars, ancestors, and other people. Thanks to these 


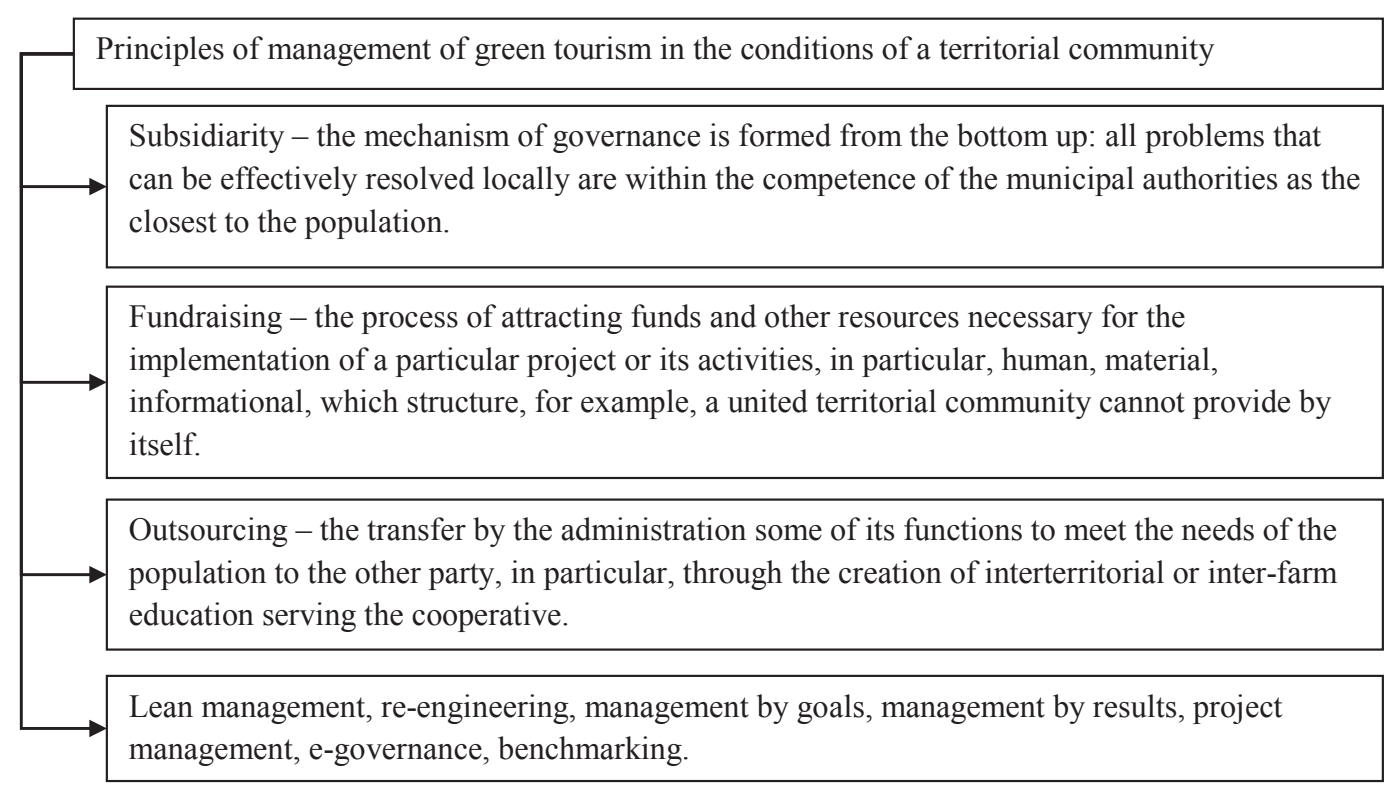

Figure 1. Principles of management of green tourism in the conditions of a united territorial community Source: formed on the basis of (Fedorchuk, 2012)

connections, a person is happy, healthy, holistic, receives support, realizes his purpose. A land plot with objects on it is indivisible and is provided to adult citizens of Ukraine free of charge, in lifetime inherited use and possession without the right to sell, with the right to transfer only to inheritance.

\section{Modelling of green tourism processes in rural areas}

The tourist does not visit just one home or one family. He/her may meet the whole community, use the infrastructure, taste local good, feel the neighbourly relations, use related services, etc. Settlement as a holistic system-synergy complex creates a multiplier effect from integration and cooperation, creating an appropriate environment (knowledge economy, economics of emotions, etc.), which, unlike competitive conditions, ensures sustainable development as a result of "powerbusiness-community" cooperation, which can join science and education in virtue of the multidimensional nature of development (Figure 2).

The determination of the magnitude of the synergistic effect from the implementation of the multifunctional approach is proposed to be evaluated depending on the rate of change and the consequences $(1)$ :

$$
\frac{\partial K(t)}{\partial t}=\left[K_{\max } \mp K(t)\left[s_{i}(t)+b_{i}(t)+p_{i}(t)\right]\right.
$$

$s_{i}(t)$ - social effect (level of employment and social security) at the time $t$;

$b_{i}(t)$ - ecological effect (level of environmental safety) at the time $t$;

$p_{i}(t)$ - economic effect (level of profitability) at the time $t$;
$K_{\max }$ - maximum capacity of the environment;

$K(t)$ - the degree of influence on the size of the potential of the medium (has a negative value in the case of a decrease, positive - increase) (Plotnikova, 2017).

There are more than 100 Family Homesteads established in Ukraine. All of them are at different stages of formation. Their inhabitants are mostly young people with higher education, who provide themselves with clean food, lead a healthy lifestyle, reveal their creative potential. The average age of settlers is $35 \pm 5$ years (Meulen, 2013; Vasiliev, 2017; Vidickiene, 2013). The synergistic effect is achieved as a result of the interaction of "environmental resources - personal skills infrastructure support" in harmony with the laws of the universe without additional funding from the side of the state (Christian, 2003; Gilman, 2013).

The main type of income is the practice of multifunctional green tourism. Investments in rural areas of individuals through the Family Homestead mechanism are a way of investing in the revival of territories when the investor does not demand the return of deposits and receives income and profits on them. The inclusion of each member of the community and society activates and multiplies the natural resource potential. The management of family settlements is carried out on the principles of participatory management. An example of practical implementation of the approach is the experience of the Nesolon village council of Novohrad-Volynskyi district of Zhytomyr region. The realization of functions of its activity is through the creation of self-sufficient and self-restoring ecological system, educational and cultural activity, development of personal characteristics of a person, provision of food, energy, cultural, economic security. 


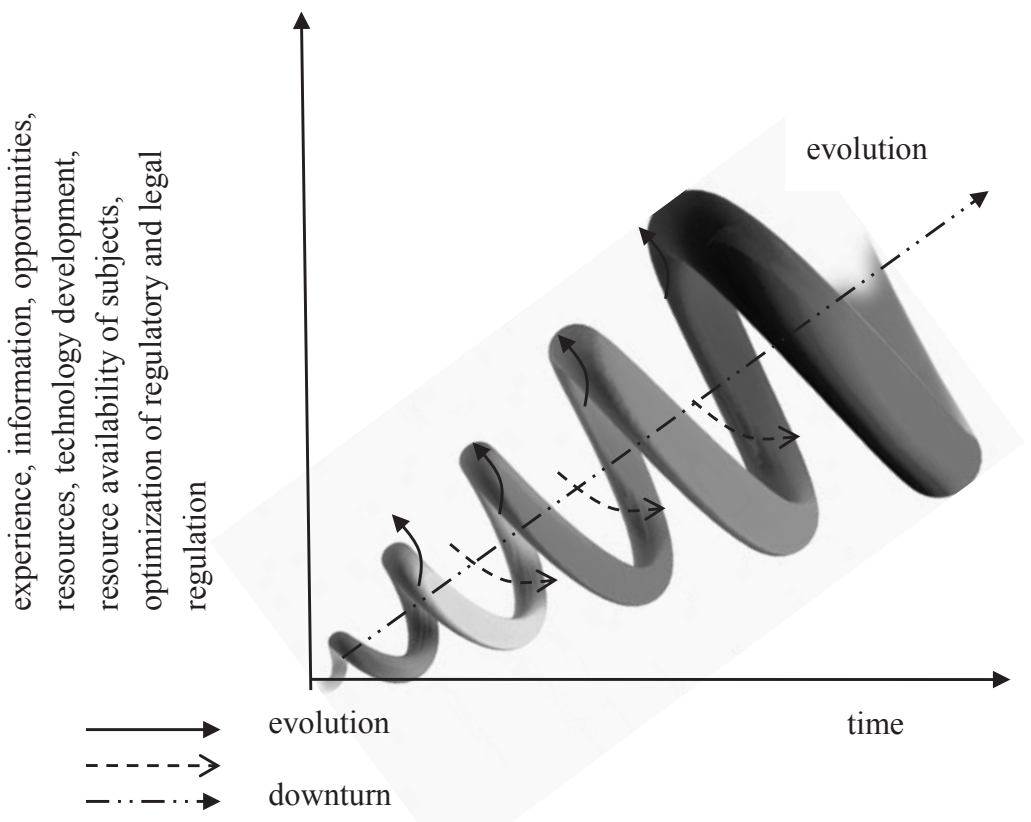

Figure 2. Development of the socio-economic system of the united territorial community as a result of green tourism in Family Homesteads

Source: formed on the basis of (Prysiazhniuk, 2018)

The means of ensuring the development of settlers is artisanal, recreational, educational, cultural, recreational, research and development activities. There is a positive tendency to increase the number of settlers, their desire to give birth to children and find multifunctional solutions to the challenges of rural development and national renaissance. The current practice in Ukraine has shown that the arrangement of Family Homesteads and providing everything necessary for normal life involves investing not less than 300 thousand UAH for 10 years, planting green fences, non-fruit trees of at least $30 \%$ of the area, as well as creating a self-sufficient and harmonious ecosystem, requiring minimal human intervention for its functioning. If you accept the average area of the village 250 hectares allocated for the Family Homestead, then for 10 years the investments of private individuals in the Family Homestead will amount to 75 million UAH, ecologically clean products will be grown to the amount of 2.5 million UAH (Table 3 ).

The revival of 600 settlements removed from the map of Ukraine during the years of independence, and 600 villages that are on the brink of extinction, will provide employment for 100 thousand middle-aged workers, the arrival of private investment in the amount of 9 billion UAH, the production of environmentally friendly products in the amount of 3 billion UAH. In these settlements, 100-150 thousand hectares of forest plantations will be planted and 3 billion UAH saved budget allocations for soil protection measures (Vasiliev, 2014). Rural employment growth will cause growth in the service sector, the establishment of service cooperatives, new productions, including high-tech, preservation and restoration of the functioning of cultural institutions, kindergartens and other social and industrial facilities.

The measures described will promote the development of the economy of family budgets, physical health of the people, reducing the burden on the infrastructure of cities, the development of new settlements and the creation of new jobs. Adoption and implementation of the provisions of the Law of Ukraine "On Family Estates and Settlements" will ensure the irreversible development of the Ukrainian family at a qualitatively new moral and psychological level that will have strategic positive consequences. The prerogative of the

Table 3

Estimation of annual results of the development of local settlements through the implementation of the idea of Family Homestead

\begin{tabular}{|l|c|c|}
\hline \multicolumn{1}{|c|}{ Indicators } & As per 1 kindergarten, thousand UAH & Together, billion UAH \\
\hline 1) Investments of individuals in the arrangement of tribal estates & 30 & 9 \\
\hline 2) Production of clean agricultural products & 25 & 7,5 \\
\hline 3) Savings of budget funds for amelioration works & 20 & 3 \\
\hline $\begin{array}{l}\text { 4) Provision of employment, including persons involved, } \\
\text { thousand persons }\end{array}$ & & 100 \\
\hline
\end{tabular}


countryside is realized in family estates: preservation of family values, development of national culture, history, traditions, revival and multiplication of natural resource potential of the territory. The settlers conduct joint work on separate garbage collection, an increase of soil fertility, purification of water and air; the introduction of noosphere education on the principle of "Health of the Earth is human health." The successful practice of green tourism in rural areas through the practice of implementing the idea of a Family Homestead involves the formation of a Strategy and Program for the development of the tourism industry in the united territorial community, which includes the following provisions: 1) statutory and legal definition of nature of the Family Homestead as an independent subject of economic activity and life, among its elements is forest with berries and mushrooms, crater garden, pondaquarium, beekeeping, active use of renewable energy sources, practice of recreation and healing, including at the expense of techniques of aromatherapy, apitherapy, hippotherapy and other elements that are harmoniously incorporated into the natural environment of the area;

2) Creation of "tourist chains" - interconnected routes and systems between separate farmsteads of a settlement with sufficiently developed infrastructure, in particular, road economy.

\section{Conclusions}

1. The existing problems in the development of rural areas identified the need to seek innovative approaches to ensure their socio-environmental sustainability and economic development. The practice of green tourism allows providing food and economic safety of the village family, solving the housing and demographic problem in the state through the implementation of the idea of Family Homestead without additional funding from the budgets of all levels. Given the rapid return on investments and the wide range of services that can be provided, the development of green tourism has prospects for its development throughout Ukraine.

2. The multifunctional nature of the development of rural areas through the Family Homestead mechanism allows the development of both agricultural and nonagricultural activities expanding the tools and practices of green and rural tourism, including through volunteer and environmental protection activities, educational and production practices, to which are actively involved by foreign citizens.

3. The development of green tourism and tribal settlements on a country scale will allow employment of 100 thousand people annually, will increase the level of food and economic security of households, and will promote the revival of the network of settlements in rural areas.

The prospects for further research are aimed at developing mechanisms for ensuring multi-functional rural development practices and corresponding planning of rural areas through the Family Homestead mechanism.

\section{References:}

Beck D.E., Cowan Ch.C. (1995). Spiral Dynamics: Mastering Values, Leadership and Change. - Lyington: Blackwell Publishing Ltd, $158 \mathrm{p}$.

Bednarska M.A. (2017). Does the Effect of Person-Environment Fit on Work Attitudes Vary with Generations? Insights from the Tourism Industry. International Journal Of Management And Economics, Vol. 53, Issue 1, pp. 65-83.

Benner M. (2017). From Clusters to Smart Specialization: Tourism in Institution-Sensitive Regional Development Policies. Economies, Vol. 5, Issue 3, Article Number 26.

Bukowska G., Repin K. (2017). Siljsjkyj turyzm: problemy zakonodavchogho reghuljuvannja [Rural tourism: problems of legislative regulation]. Zemlevporjadnyj visnyk, Vol. 7, pp. 30-34. (in Ukrainian)

Christian D.L. (2003). Creating a Life Together: Practical Tools to Grow Ecovillages and Intentional Communities. Retrieved from: https://archive.org/details/fa_Creating_a_Life_Together-Practical_Tools_to_Grow_Ecovillages_ and_Intent ional_Com (accessed 08.03.2018)

Dafuleya G., Gyekye A.B., Oseifuah E.K., et al. (2017). Religiously motivated travel and rural tourism in Vhembe District of South Africa. Tourism Economics, Vol. 23, Issue 4, pp. 911-918.

Database (2018). State Committee of Statistics of Ukraine. Retrieved from: http://www.ukrstat.gov.ua/operativ/ operativ2005/ds/ator/kn_arh05_u.html (accessed 08.03.2018)

Fedorchuk A.V. (2012). Innovacijnyj mekhanizm derzhavnogho upravlinnja: pidkhody do formuvannja [Innovative mechanism of public administration: approaches to the formation]. Efficiency of public administration, Vol. 33, pp. 150-157. (in Ukrainian)

Gilman R. (2013). The Eco-village Challenge. The challenge of developing a community living in balanced harmony - with itself as well as nature - is tough, but attainable. Retrieved from: http://www.context.org/iclib/ ic29/gilman1/ (accessed 08.03.2018)

Jaszczak A., Žukovskis J., Antolak M. (2017). The Role Of Rural Renewal Program In Planning Of The Village Public Spaces: Systematic Approach. Management Theory and Studies for Rural Business and Infrastructure Development, Vol. 39, No. 4, pp. 432-441.

Lalu F. (2016). Opening the organization of the future, Moscow: LLC "Mann, Ivanov and Ferber", 610 p. (in Russian) 
Leonidova E.G. (2017). Domestic Tourism Development in a Region. Economic And Social Changes-Facts Trends Forecast, Vol. 50, Issue 2, pp. 271-283.

Lupu N. (2016). Sustainable Tourism, between social Responsibility and non-financial Reporting. Amfiteatru Economic, Vol. 18, Special Issue 10, pp. 737-739.

Machado Ch., Esther L. (2017). Model for integrated community tourism in ecuador, case study pastaza. Revesco-Revista De Estudios Cooperativos, Issue 123, pp. 250-275.

Meulen C., Palojarvi A., Pyysiainen J., Saloranta M. (2013). Inspiring stories from eco-villages: experience with ecological technologies and practices, Vilnius: BMK Leidykla, $120 \mathrm{p}$.

Nitsenko V., Nyenno I., Kryukova I., Kalyna T., Plotnikova M. (2017). Business Model For A Sea Commercial Port As A Way To Reach Sustainable Development Goals. Journal Of Security And Sustainability Issues, Vol. 7, Number 1, pp. 155-166. Retrieved from: http://doi.org/10.9770/jssi.2017.6.4(13) (accessed 08.03.2018)

Nizic M.K., Grdic Z.S., Endres R. (2017). Energy Sustainability and Its Impacts on Croatian Tourism. Croatian Economic Survey, Vol. 19, Issue 2, pp. 83-104.

On Personal Peasant Economy (2003). The law of Ukraine with amendments and additions of 05.04.2015. Vedomosti Of The Verkhovna Rada Of Ukraine, No 29, Article 232. Retrieved from: http://zakon5.rada.gov.ua/ laws/show/742-15 (accessed 08.03.2018) (in Ukrainian)

On Tourism (1995). The law of Ukraine with amendments and additions of 11.02.2015. Vedomosti Of The Verkhovna Rada Of Ukraine, No 31, Article 241. Retrieved from: http://zakon2.rada.gov.ua/laws/show/324/ 95-\%D0\%B2\%D1\%80 (accessed 08.03.2018) (in Ukrainian)

Plotnikova M.F. (2017). Modeljuvannja baghatofunkcionaljnogho rozvytku siljsjkykh terytorij v umovakh ghlobalizaciji ta decentralizaciji vladnykh povnovazhenj [Modeling of multifunctional development of rural areas in the context of globalization and decentralization of power]. Bulletin of KHNAU im. V.V. Dokuchaeva. Series "Economic Sciences", Vol. 3, pp. 95-105. (in Ukrainian)

Prysiazhniuk O., Plotnikova M., Buluy O. (2018). Cluster approach in administration of rural areas. Management Theory and Studies for Rural Business and Infrastructure Development, Vol. 40, No. 2, pp. 118-127.

Reyes V.M.V., Ortega O.A.F., Noonan D.S., Rizzo I. (2017). Economics of cultural tourism: issues and perspectives. Journal Of Cultural Economics, Vol. 41, Issue 2, Special Issue, pp. 95-107.

Vasiliev M.L., Grabar I.G., Jolly S.V., Plotnikov N.F (2017). Ancestral Homestead: economy, technology, communication, ecology. Zhytomyr: Ruta, 272 p. (in Ukrainian)

Vasiliev M.L., Plotnikova N.F. (2014). Perspektyvy rozvytku siljsjkykh terytorij ta Koncepcija «Rodovoji sadyby»: socialjno-ekologhichnyj aspekt [Prospects of development of rural areas And the concept of "Family estate": socio-environmental aspect]. Bulletin ZNAEU, Vol. 2, Issue 4, Part 2, pp. 412-423. (in Ukrainian)

Vidickiene D. (2013). Living in harmony: inspiring stories from ecovillages. - Vilnius: BMK Leidykla, 124 p.

Zinchenko Ie., Taratula G.B., Foot M. (2016). Land and resource potential of recreational areas. - Luck: I Nadster, 216 p. (in Ukrainian) 